\title{
Revision of Protohydnum (Auriculariales, Basidiomycota)
}

\section{Malysheva, Vera}

2018-07

Malysheva, V, Spirin , V, Miettinen, O, Motato-Vasquez , V, Hernawati, Seelan , J S S \& Larsson , K-H 2018 , ' Revision of Protohydnum (Auriculariales, Basidiomycota) ' , Mycological Progress , vol. 17 , no. 7 , pp. 805-814 . https://doi.org/10.1007/s11557-018-1393-6

http://hdl.handle.net/10138/326187

https://doi.org/10.1007/s11557-018-1393-6

unspecified

acceptedVersion

Downloaded from Helda, University of Helsinki institutional repository.

This is an electronic reprint of the original article.

This reprint may differ from the original in pagination and typographic detail.

Please cite the original version. 
Vera Malysheva ${ }^{1}$, Viacheslav Spirin ${ }^{2,3 *}$, Otto Miettinen ${ }^{2}, V_{i v i a n a}$ Motato-Vásquez ${ }^{4}$, Hernawati ${ }^{5,6}$, Jaya Seelan Sathiya Seelan $^{7}$, Karl-Henrik Larsson ${ }^{3}$

${ }^{1}$ Komarov Botanical Institute, Russian Academy of Sciences, Prof. Popova str. 2, 197376 St. Petersburg, Russia

${ }^{2}$ Finnish Museum of Natural History, University of Helsinki, PO Box 7, 00014 University of Helsinki, Finland

${ }^{3}$ Natural History Museum, University of Oslo, P.O. Box 1172, Blindern, 0318 Oslo, Norway

${ }^{4}$ Instituto de Botânica, Núcleo de Pesquisa em Micologia, Av. Miguel Estéfano 3687, São Paulo, SP CEP 04301-012,

Brazil

${ }^{5}$ The Herbarium (ANDA), Universitas Andalas, Padang, Sumatera Barat 25163, Indonesia

${ }^{6}$ Fakultas Kehutanan (Faculty of Forestry, Universitas Muhammadiyah Sumatera Barat, Padang, Sumatera Barat 25172, Indonesia.

${ }^{7}$ Mycology and Pathology Laboratory, Institute for Tropical Biology and Conservation (ITBC), Universiti Malaysia Sabah, 88400 Kota Kinabalu, Sabah, Malaysia

* Corresponding author: Viacheslav Spirin, viacheslav.spirin@ helsinki.fi, +358465918235 


\section{Abstract}

Three species currently addressed to Protohydnum (Auriculariales) are studied with morphological and DNA methods. The genus Protohydnum is retained for the type species only, P. cartilagineum, recently re-collected in Brazil. The European species, $P$. piceicola, is not congeneric with P. cartilagineum and, therefore, placed in its own genus, Hyalodon, gen. nov. Another Hyalodon species, H. antui, is described from East Asia. The third member of Protohydnum sensu lato, $P$. sclerodontium from South-East Asia, is transferred to Elmerina.

Key words: heterobasidiomycetes; hydnoid fungi; phylogeny; taxonomy

Introduction

Protohydnum A. Möller is a genus of the order Auriculariales (Basidiomycota) with three currently accepted species, $P$. cartilagineum A. Möller (the genus type), P. piceicola Kühner ex Bourdot, and P. sclerodontium (Berk. \& Mont.) Hjortstam \& Spooner. The placement into one genus rests on common morphological features, such as totally resupinate basidiocarps with well-developed, gelatinized spines, and a presence of thick-walled hyphae in tramal tissue (Hjortstam et al. 1990, Roberts 1998). However, no proper revision of the genus has been carried out so far, mainly due to the absence of $P$. cartilagineum type material, as well as recent collections of the latter species.

In 2017, a resupinate hydnoid fungus fitting to the protologue and original illustrations of $P$. cartilagineum (Möller 1895) was collected in southern Brazil. This record allowed us to compare P. cartilagineum with specimens of $P$. piceicola from Europe and East Asia, as well as collections of $P$. sclerodontium from South-East Asia. The results from this study are presented below.

Materials and methods

Morphological study. Specimens from the herbaria SP, H, O, GB, K, SNP, MAN, and ANDA were studied. Herbarium names are abbreviated according to Thiers (2017). Microscopic routine follows Miettinen et al. (2012). All observations and measurements were made from microscopic slides prepared in Cotton Blue, using phase contrast and oil immersion lens (Leitz Diaplan microscope, $\times 1250$ amplification). At least 30 basidiospores were measured for each studied specimen. The following abbreviations are used in morphological descriptions: $\mathrm{L}$ - mean basidiospore length, $\mathrm{W}$ - mean basidiospore width, Q' - length / width ratio, $\mathrm{Q}$ - mean length / width ratio, $\mathrm{n}$ - number of measurements per specimens.

DNA extraction and sequencing. For DNA extraction, small fragments of dried basidiocarps were used. In total, 14 specimens were selected for molecular sampling (Table 1). DNA was extracted using the NucleoSpin Plant II Kit (Macherey-Nagel GmbH \& Co. KG) according to the manufacturer's instructions. The following primers were used for both amplification and sequencing: ITS1F-ITS4 (http://www.biology.duke.edu/fungi/mycolab/primers.htm) for ITS region; primers JS1 (Landvik 1996) and LR5 (http://www.biology.duke.edu/fungi/mycolab/primers.htm) for LSU region. PCR products were purified applying the GeneJET Gel Extraction Kit (Thermo Scientific, Thermo Fisher Scientific Inc., MA, USA). Sequencing was performed with an ABI model 3130 Genetic Analyzer (Applied Biosystems, CA, USA). Raw data were edited and assembled in MEGA 6 (Tamura et al. 2013).

Phylogenetic analyses. For this study, 14 ITS and 13 nrLSU sequences were generated (Table 1). An additional 32 ITS and nrLSU sequences, including the outgroup, were retrieved from GenBank (www.ncbi.nlm.nih.gov/genbank/). Sequences were aligned with the MAFFT version 7 web tool (http://mafft.cbrc.jp/alignment/server/) using the Q-INS-i option for both markers. The final concatenated alignment contained 1613 characters (including gaps).

Phylogenetic reconstructions were performed with maximum likelihood (ML) and Bayesian (BA) analyses. Before the analyses, the best-fit substitution model for the alignment was estimated based on the Akaike Information Criterion (AIC) using FindModel web server (http://www.hiv.lanl.gov/content/sequence/findmodel/findmodel.html).

Maximum likelihood analysis was run on RAxML servers, v.7.2.8 (http://phylobench.vital-it.ch/raxml-bb/index.php), under a GTR model with one hundred rapid bootstrap replicates.

Bayesian analyses was performed with MrBayes 3.1 software (Ronquist \& Huelsenbeck 2003), for two independent runs, each with 5 million generations with sampling every 100 generations, under described model and four chains. To quickly diagnose convergence of MCMC analyses and to get estimates of the posterior distribution of parameter values Tracer v1.6 was used (Rambaut et al. 2014).

Newly generated sequences have been deposited in GenBank with corresponding accession numbers (Table 1). The alignment has been deposited in TreeBASE (22055).

Specimens examined (sequenced collections are marked by asterisk)

Bourdotia galzinii. Spain. Málaga: Mijas, Los Espartales, on a living tree (Cupressaceae), 20.XI.2012 Miettinen 15900.4* (H).

Elmerina cladophora. Indonesia. Papua Barat: Manokwari, Saukorem, Pterocarpus indicus (?), 2.XI.2010 Miettinen $14314 *(\mathrm{H})$, hardwood, 2.XI.2010 Miettinen 14337, 14349* (MAN, H). Philippines. Malamon Island, 4.II.1875 Challenger expedition (K(M) 56207, holotype).

Elmerina sclerodontia. China. Yunnan: Xishuangbanna, Mandian Nat. Res., hardwood, 15.VIII.2005 Miettinen $10330(\mathrm{H})$, 17.VIII.2005 Miettinen 10386 (H). Indonesia. Riau: Desa Sungai Maju, hardwood, 10.VII.2004 Miettinen 8899 (H). West Sumatra: Padang, Limau Manis, hardwood, 5.VII.2008 Miettinen 12784 (H). Malaysia. Sabah: Ranau, Poring, hardwood, 19.VI.2013 Miettinen 16431* (SNP 33632, H). Singapore. Nee Soon, fallen hardwood branch, 15.III.2011 Tran \&

Skornikova SING 2011-130(H). 
Hyalodon antui. China. Jilin: Antu, Changbai, Abies sp., 17.IX.1998 Niemelä 6389* (H, holotype).

Hyalodon piceicola. Finland. Etelä-Häme: Kangasala, Vatiala, hardwood, 3.X.1993 Söderholm 2138* (H). Pohjois-Karjala: Lieksa, dead polypore on Betula, 12.X.2004 Hottola 2712*(H), Picea abies, 12.X.2004 Eriksson 2021b (H). KittilänLappi: Muonio, Pallastunturi, P. abies, 21.VIII.2013 Pennanen 2501*(H). Norway. Oppland: Sel, Sagåa Nat. Res., P. abies, 13.IX.2016 Spirin 11063*(H). Russia. Khabarovsk Reg.: Khabarovsk Dist., Bolshoi Khekhtsir, Tilia amurensis, 2.IX.2013 Spirin 6536* (H). Nizhny Novgorod Reg.: Lukoyanov Dist., Panzelka, P. abies, 12.VIII.2007 Spirin 2689* (H). Primorie: Ternei Dist., Maisa, Abies sp., 10.IX.1990 Larsson 7212 (GB).

Protodaedalea hispida. Russia. Khabarovsk Reg.: Khabarovsk Dist., Birakan, T. amurensis, 10.VIII.2012 Spirin 5139* (H), Ulika, Betula platyphylla, 13.VIII.2012 Spirin 5191 (H).

Protodaedalea foliacea. Indonesia. Sumatra: Padang, Limau Manis, on a fallen tree crown, 14.VII.2008 Miettinen 796* (ANDA, H).

Protodontia subgelatinosa. Norway. Oppland: Vågå, Veogjelet, Betula pubescens, 13.IX.2016 Spirin 11079*(O). Protohydnum cartilagineum. Brazil. São Paulo: Iguape, Mosaico de Unidades de conservação Jureia-Itatíns, Rio Verde, fallen trunk, 28.VI.2017 Pires 406 (SP467240* - epitype, duplicates H, LE).

Protomerulius sp. Indonesia. Papua Barat: Manokwari, Saukorem, fallen hardwood branch, 4.XI.2010 Miettinen 14402.1* (MAN, H).

Stypella vermiformis. Norway. Møre og Romsdal: Aure, Hermundslia, Pinus sylvestris, 20.III.2004 Oldervik 135.04* (O

F188059). Russia. Nizhny Novgorod Reg.: Lukoyanov Dist., Panzelka, P. abies, 2.VIII.2017 Spirin 11330* (H).

Results

Phylogenetic analysis of the combined ITS and nrLSU dataset shows that three species previously included in Protohydnum belong to separate lineages within Auriculariales, and therefore cannot be considered congeneric (Fig 1). 1. The generic type, $P$. cartilagineum, is recovered in a clade encompassing Bourdotia spp. and Ductifera sucina (bs = $96 \%, \mathrm{pp}=1$ ). This lineage was first recognized by Weiss \& Oberwinkler (2001) and then consisted of Bourdotia galzinii (Bres.) Bres. \& Torrend (effused species) and two Ductifera spp. (with lobed, Exidia-like fructifications). They stressed that these taxa were morphologically highly similar and even proposed to unite Bourdotia (Bres.) Bres. \& Torrend and Ductifera Lloyd into one genus although no formal recombination of B. galzinii to the older genus Ductifera was made. According to our data, this lineage contains at least two more species, P. cartilagineum and an unnamed 'Bourdotia' sp. GEL 5065. Basidia of B. galzinii have been described as 'petiolate', possessing an ellipsoid apical part longitudinally divided into four equal cells and an enucleate stalk gradually tapering to the base (Wells \& Raitviir 1975). Basidia of the same kind occur in P. cartilagineum; however, the latter species lacks gloeocystidia. In turn, Ductifera spp. have typical Exidia-like, 'sessile' basidia devoid of a basidial stalk but provided with conspicuous gloeocystidia (Wells 1958, Weiss \& Oberwinkler 2001). If also macroscopic diversity of these taxa is taken into account, it is difficult to justify that these taxa are placed into one genus (in this case, Protohydnum would have a priority over Ductifera and Bourdotia). We leave this problem unsolved until DNA studies with more markers are available and keep Protohydnum as a monotypic genus. 2. Protohydnum piceicola is detected as a sister taxon of Heterochaetella ( $\mathrm{bs}=97 \%, \mathrm{pp}=1$ ), in accordance with earlier studies of Weiss \& Oberwinkler (2001) and Zhou \& Dai (2013). These taxa are morphologically similar due to thickwalled hyphae and sphaeropedunculate basidia provided with an enucleate stalk of the same diameter along its whole length (as opposed to petiolate basidia of Bourdotia - Wells \& Rairviir 1975). However, Heterochaetella dubia (Bourdot \& Galzin) Bourdot \& Galzin (the genus type) and its relatives produce well-developed, thick-walled cystidia, and none of them develop the kind of distinctly hydnoid hymenophore so characteristic of P. piceicola. In our opinion, these differences preclude a transfer of $P$. piceicola to Heterochaetella. The morphological evidence is in good accordance with phylogenetic data (Fig. 1). Although belonging to the same lineage as $P$. piceicola, Heterochaetella is still rather distant and closer to two unnamed Protomerulius species whose sequences are very similar to those ones of $P$. brasiliensis A. Möller (the generic type of Protomerulius), P. africanus (Ryvarden) Ryvarden and P. substuppeus (Berk. \& Cooke) Ryvarden (cf. Zhou \& Dai 2013). For this reason P. piceicola should be kept separate from both Heterochaetella and Protomerulius and a new genus, Hyalodon, is introduced. A second Hyalodon species from East Asia is also described here. Martin (1952) mechanically combined $P$. piceicola in Protodontia Höhn., typified with P. subgelatinosa (P. Karst.) Pilát. These species are, however, only superficially similar, and they are not closely related according to DNA data (Fig. 1).

3. Protohydnum sclerodontium is the closest relative of Elmerina cladophora (Berk.) Bres., the generic type of Elmerina Bres., differing from the latter by $11 \mathrm{bp}$ throughout the ITS region. The two are clearly congeneric, and we combine $P$. sclerodontium to Elmerina. The generic concepts for poroid Auriculariales should be properly evaluated. Zhou \& Dai (2013) accepted only two poroid genera in the order - Elmerina Bres. 1912 in a wide sense (including Aporpium Bondartsev \& Singer 1944 and Protodaedalea Imazeki 1955) and Protomerulius A. Möller 1895. This decision was mainly based on DNA data and, in general, it follows the morphology-based concept of Elmerina presented by Parmasto (1984) and Reid (1992). Sotome et al. (2014) proposed a more nuanced solution for the Elmerina complex based on both morphological and phylogenetic studies. Two genera, Aporpium and Protodaedalea, were reinstated and re-described. At the same time, the identity of Elmerina, limited by the authors to the type species, was left untouched, due to absence of DNA sequences. Our data show that the type of Elmerina is nested within Aporpium sensu Sotome et al. (2014). Based on existing data, we think that the one genus option for the Elmerina clade is not an optimal solution; it would be premature to conclude that Aporpium and Protodaedalea should be fused with Elmerina.

Our phylogenetic analysis - admittedly quite scanty in species sampling - shows that the Elmerina clade can be further divided into morphologically distinct subclades (Fig. 1). The subclade that includes the type species of Elmerina is 
restricted to species with soft-leathery, flexible basidiocarps and largely poroid or (in one species) clavarioid hymenophore. Distinctly cyanophilous, rather wide skeletal hyphae with a broad lumen, hymenial cystidia and hyphidia, as well as stipitate ('petiolate') basidia characterize all species of Elmerina while long hyphal pegs are restricted to the poroid species. Protodaedalea is similar to Elmerina in terms of basidiocarp consistency, and shape of basidia and basidiospores. However, Protodaedalea spp. are monomitic, with agglutinated, coloured and sclerified hyphae deep in tube trama, and they possess narrow and richly branched dendrohyphidia occurring in sterile pegs. The hymenophore of both Protodaedalea foliacea (Pat.) Sotome \& T. Hatt. and P. hispida Imazeki is lamellate from the very beginning while the lamellae of E. cladophora develop through the elongation and fusion of pores, and they occur mainly in intensively growing, reflexed parts. In turn, Aporpium embraces species with sturdier and rather small-pored basidiocarps. Hyphal pegs and hyphidia are absent in Aporpium spp., skeletal hyphae have a capillary lumen or are solid, and basidia are sessile (not stipitate) (Miettinen et al. 2012). Moreover, basidiospores of Aporpium are cylindrical or bean-shaped, often clearly curved, in contrast to fusiform or ellipsoid basidiospores of Elmerina and Protodaedalea spp. However, it should be stressed that wider sampling of poroid taxa, especially from tropical areas, is needed before a decision on genus limits within the Elmerina lineage.

\section{Taxonomy}

Protohydnum A. Möller, Botanische Mittheilungen aus den Tropen 8: 173, 1895.

According to our current knowledge, Protohydnum must be restricted to the type species. Hjortstam et al. (1990) studied a specimen of $P$. cartilagineum from Panama and stated it was 'undoubtedly dimitic'. This statement certainly contradicts our observations and most probably refers to another, unrelated species. From two other genera dealt with in this paper, Protohydnum s.str. differs by a truly monomitic hyphal structure with thin-walled, clamped hyphae, and by lacking cystidia.

Protohydnum cartilagineum A. Möller, Botanische Mittheilungen aus den Tropen 8: 131, 1895. - Figs. 2, 5. Lectotype. Table 3, plate 1 in A. Möller, Protobasidiomyceten, Botanische Mittheilungen aus den Tropen 8, 1895 (selected here). Epitype. Brazil. São Paulo: Iguape, Mosaico de Unidades de conservação Jureia-Itatíns, Rio Verde, fallen trunk, 28.VI.2017, Pires 406 (SP467240) (selected here).

Basidiocarps resupinate, extensive, covering several decimeters, opaque, cartilagineous, yellowish white in fresh condition, tough and with ochraceous or brownish tints after drying. Subiculum distinct, ochraceous-brownish, in dry condition vernicose, well visible. Spines blunt, simple or occasionally fusing in groups of 2-4, more or less regularly arranged, 1-3 $\mathrm{mm}$ long, 0.5-1 mm in diam., 8-11 per $\mathrm{cm}$, with a white compact core in section. Hyphal structure monomitic. Hyphae hyaline, thin-walled, clamped, densely covered by crystals in the spine core, embedded in gelatinous matrix in subhymenium, $2-4 \mu \mathrm{m}$ in diam., occasionally inflated up to $5 \mu \mathrm{m}$ in diam., not cyanophilous. Cystidia absent, hyphidia abundant, richly branched, covering the hymenial surface, $2-3 \mu \mathrm{m}$ in diam. at the apex. Basidia 4-celled, ellipsoid, petiolate, embedded, $14.5-20 \times 8.5-10 \mu \mathrm{m}$, stalk up to $20 \times 3.5-4.5 \mu \mathrm{m}$, sterigmata up to $21 \times 2.5-3 \mu \mathrm{m}$. Basidiospores smooth, thin-walled, cylindrical-fusiform to ellipsoid-ovoid, (8.1-) 8.2-11.2 (-11.8) × (3.4-) 3.7-4.8 (-5.1) $\mu \mathrm{m}(\mathrm{n}=30 / 1)$, $\mathrm{L}=9.47, \mathrm{~W}=4.21, \mathrm{Q}^{\prime}=(1.8-)$ 1.9-2.8 (-3.0), $\mathrm{Q}=2.30$, repetitive.

Remarks. Protohydnum cartilagineum is a characteristic species due to its largely effused, cartilagineous basidiocarps with thick, blunt spines, stalked basidia and predominantely fusiform basidiospores. Möller (1895) and Lowy (1971) stated that the basidiospores of this species are not repetitive. However, we detected at least two repetitive basidiospores per 30 measured ones. So far, P. cartilagineum is known from the southern part of Brazil (Santa Catarina and São Paulo). In addition, it has been reported from Guyana, Mexico and Panama (Martin 1952, Lowy 1971, Hjortstam et al. 1990) although identity of this material should be re-checked.

Hyalodon V. Malysheva \& Spirin, gen. nov. MB 823910

Basidiocarps resupinate, semitranslucent, gelatinous, greyish white in fresh condition, often with ochraceous or brownish tints after drying. Subiculum very thin, observable mostly at young stages of the basidiocarp's development. Spines sharppointed, simple or accidentally branched, more or less regularly arranged, 1-3 mm long, 50-70 $\mu \mathrm{m}$ in diam., 3-6 per mm. Hyphal structure monomitic. Tramal hyphae hyaline to brownish, slightly to distinctly thick-walled, rarely clamped, encrusted, moderately cyanophilous. Subhymenial hyphae hyaline, thin-walled, often short-celled and frequently clamped. Cystidia and hyphidia absent. Basidia 4-celled, ovoid to globose, pedunculate or sessile, forming a continuous hymenial layer, with thickened walls after spore detachment. Basidiospores smooth, thin-walled, broadly ellipsoid to subglobose, 4.5-7 $\times 4-5 \mu \mathrm{m}$, often with a large central oil drop, repetitive. Often on wood of conifers, rarely on deciduous trees, dead polypores and fern remnants.

Genus type. Protohydnum piceicola Kühner ex Bourdot.

The two species accepted in the new genus develop long, slender spines on a thin, adnate subiculum. Subicular hyphae are thin-walled, interwoven and densely glued together, occasionally bearing normally developed basidia (Fig. 3). Hyphal structure of spines is more complex due to clear differences between subparallel, slightly or distinctly thick-walled, densely arranged tramal hyphae and short-celled, certainly thin-walled hyphae in the subhymenium. Roberts (1998) named this 
structure pseudodimitic. We feel that this designation is more confusing than explaining, because pseudodomitic has obtained a quite different meaning in taxonomy of polypores (summarized in Spirin \& Zmitrovich 2007). Thick-walled hyphae in Hyalodon spp. are regularly but rather rarely septate and clamped, and their diameter is more or less constant along their length. Therefore, we consider a hyphal structure of this kind as monomitic.

Hyalodon antui Spirin \& V. Malysheva, sp. nov. - Fig. 3.

Holotype. China. Jilin: Antu, Changbai, Abies sp., 17.IX.1998 Niemelä 6389 (H).

MB 823911

Basidiocarps largely effused, up to $20 \mathrm{~cm}$ in largest dimension. Spines 3-4 per $\mathrm{mm}$. Subiculum well-developed, easily visible in dry condition, vernicose. Tramal hyphae subparallel, slightly to distinctly thick-walled (wall up to $1 \mu \mathrm{m}$ thick), $2-$ $3.5 \mu \mathrm{m}$ in diam. Basidia $8-10.5 \times 8-9.5 \mu \mathrm{m}$, stalk up to $10 \times 1.5-3 \mu \mathrm{m}$, sterigmata up to $6 \times 2-3 \mu \mathrm{m}$. Basidiospores $(5.2-)$ 5.4-6.9 (-7.0) × 4.2-5.2 $\mathrm{m}(\mathrm{n}=30 / 1), \mathrm{L}=6.09, \mathrm{~W}=4.73, \mathrm{Q}^{\prime}=(1.1-) 1.2-1.5(-1.6), \mathrm{Q}=1.29$.

Remarks. Hyalodon antui differs from $H$. piceicola in having a distinct subiculum, more sparsely arranged spines, and larger basidiospores. The species is so far known from the type locality only.

Hyalodon piceicola (Kühner ex Bourdot) V. Malysheva \& Spirin, comb. nov. - Fig. 4, 5.

$\equiv$ Protohydnum piceicola Kühner ex Bourdot, Bull. Soc. Mycol. France 48: 205, 1932.

MB 823912

Basidiocarps small or medium-sized, up to $8 \mathrm{~cm}$ in largest dimension. Spines 5-6 per mm. Subiculum poorly developed, detectable in dry condition under a lens only. Tramal hyphae subparallel, slightly to distinctly thick-walled (wall up to 0.7 $\mu \mathrm{m}$ thick), 1.5-3 $\mu \mathrm{m}$ in diam. Basidia 7.5-9 $\times 6.5-8.5 \mu \mathrm{m}$, stalk up to $7 \times 1.5-3 \mu \mathrm{m}$, sterigmata up to $8 \times 2-3 \mu \mathrm{m}$. Basidiospores (4.2-) 4.3-6.1 (-6.2) × (3.8-) 3.9-5.0 (-5.1) $\mu \mathrm{m}(\mathrm{n}=120 / 4), \mathrm{L}=4.94-5.51, \mathrm{~W}=4.28-4.36, \mathrm{Q}^{\prime}=(1.0-)$ $1.1-1.4(-1.5), \mathrm{Q}=1.15-1.29$.

Remarks. Hyalodon piceicola is widely distributed in temperate - boreal, conifer-dominated forests of Eurasia although it is uncommon. It usually occurs on fallen branches or logs of Picea abies, more rarely on decayed wood of other trees, as well as on rotten polypores. Protodontia filicina Parmasto (1962) was described based on two specimens from fern remnants. Morphologically, it is hardly distinguishable from $H$. piceicola and they may be conspecific. However, no recent material of $P$. filicina is available, and we leave this question open.

Elmerina Bres., Ann. Mycol. 10: 507, 1912.

= Tremellacantha Jülich, Bot. J. Linnean Soc. 81: 44, 1980 .

Bresadola (1911) described Elmeria for two species, E. cladophora (Berk.) Bres. and E. vespacea (Pers.) Bres. Later he realized this genus name is a homonym of Elmeria Ridl. (Saxifragaceae) and thus renamed it Elmerina (Bresadola 1912). New combinations for the two species included in the earlier description of Elmeria was made a year later (Bresadola 1913). Clements \& Shear (1931) selected E. cladophora as the type of the genus. As explained above, the latter species is closely related to Hydnum sclerodontium Mont. \& Berk. previously considered a member of Protohydnum (Hjortstam et al. 1990, Roberts \& Spooner 1998). Jülich (1980) introduced a new genus, Tremellacantha, for H. sclerodontium. Here Tremellacantha is placed as a synonym of Elmerina.

Elmerina sclerodontia (Mont. \& Berk.) Miettinen \& Spirin, comb. nov. - Fig. 5.

$\equiv$ Hydnum sclerodontium Mont. \& Berk., London J. Bot. 3: 333, 1844. Lectotype. Indonesia. Java, coll. Spanoghe (K) (selected and studied by Hjortstam et al. 1990).

MB 823913

This peculiar fungus is widely distributed in tropical forests of South-East Asia, occurring on fallen logs and dry branches of angiosperm trees, often in open localities. A modern description of the species was given by Hjortstam et al. (1990). They regard the species as hydnoid, but usually this term is restricted to species whose spines grow downwards, whereas in the case of E. sclerodontia the "spines" grow upwards from a continuous, sterile subiculum, and even branch occasionally. Usually this kind of basidiome type is called clavarioid or furcate. The only somewhat similar basidiomes in Auriculariales belong to Tremellodendropsis sensu lato in the Protomerulius clade (Weiss \& Oberwinkler 2001, Berbee et al. 2016).

\section{Acknowledgements}

The research was supported by the project of the Komarov Botanical Institute "Biodiversity and spatial structure of fungi and myxomycetes communities in natural and anthropogenic ecosystems" (the author VM), by Norwegian Biodiversity Information Centre (project "A survey of Norwegian jelly fungi”, grant number knr. 44-15) (the authors VS and KHL) and Coordenação de Aperfeiçoamento Pessoal de Nível Superior - CAPES- Brazil (the author VMV). We thank Herbarium of Andalas University, Sabah Parks, BORNEENSIS (Universiti Malaysia Sabah) and Sabah Biodiversity Council for their assistance to conduct field work (permit to the author JSSS). We thank Mr. Rolinus Paulus for helping at the fieldwork in Sabah. Ricardo M. Pires (Instituto de Botânica, São Paulo) kindly provided us with the specimen of P. cartilagineum and Tuomo Niemelä (University of Helsinki) with the specimen of Hyalodon antui. Alexander Sennikov (University of Helsinki) advised us about nomenclatural problems.

References

Berbee ML, Wong EYY, Tsui CKM (2016) Phylogenetic evidence places the coralloid jelly fungus 
Tremellodendropsis tuberosa (Tremellodendropsidales) among early diverging Agaricomycetes. Mycol Prog 15: 939-946. Bresadola G (1911) Fungi Borneensis. Ann Mycol 9: 425-428.

Bresadola G (1912) Polyporaceae Javanicae. Ann Mycol 10: 492-508.

Bresadola G (1913) Basidiomycetes Philippinenses. Series II. Hedwigia 53: 44-80.

Clements FE, Shear CL (1931) The genera of fungi. NY: H.W. Wilson. 496 p.

Hjortstam K, Spooner BM, Oldridge SG (1990) Some Aphyllophorales and heterobasidiomycetes from Sabah, Malaysia.

Kew Bulletin 45: 303-322.

Jülich W (1980) Notulae et novitates Muluensis. Bot J Linnean Soc 81: 43-46.

Landvik S (1996) Neolecta, a fruit-body producing genus of the basal ascomycetes, as shown by SSU and LSU rDNA sequences. Mycol Research 100: 199-202.

Lowy B (1971) Tremellaceae. Flora Neotropica 6: 1-153.

Lutzoni F, Kauff F, Cox CJ, McLaughlin D, Celio G, Dentinger B, Padamsee M, Hibbett D, James TY, Baloch E, Grube M, Reeb V, Hofstetter V, Schoch C, Arnold AE, Miadlikowska J, Spatafora J, Johnson D, Hambleton S, Crockett M, Shoemaker R, Sung GH, Lücking R, Lumbsch T, O’Donnell K, Binder M, Diederich P, Ertz D, Gueidan C, Hansen K, Harris RC, Hosaka K, Lim YW, Matheny B, Nishida H, Pfister D, Rogers J, Rossman A, Schmitt I, Sipman H, Stone J, Sugiyama J, Yahr R, Vilgalys R (2004) Assembling fungal tree of life: progress, classification, and evolution of subcellular traits. American J Bot 91: 1446-1480.

Martin GW (1952) Revision of the North Central Tremellales. State Univ Iowa Studies Nat Hist 19 (3): 1-122.

Miettinen O, Spirin V, Niemelä T (2012) Notes on genus Aporpium (Auriculariales, Basidiomycota), with a new species from temperate Europe. Ann Bot Fennici 49: 359-368.

Möller A (1895) Protobasidiomyceten. Botanische Mittheilungen aus den Tropen 8: 1-180.

Parmasto E (1962) Species varietatesque nova fungorum. Tremellales et Aphyllophorales. Bot Mat Otdela Spor Rast 15: 125-137.

Parmasto E (1984) The genus Elmerina (Polyporaceae s.str.). Nova Hedwigia 39: 101-116.

Rambaut A, Suchard MA, Xie D, Drummond AJ (2014) Tracer v1.6. http://tree.bio.ed.ac.uk/software/tracer/ (accessed on 20.12.2017)

Reid DA (1992) The genus Elmerina (Tremellales), with accounts of two species from Queensland, Australia. Persoonia 14: $465-474$.

Roberts P (1998) A revision of the genera Heterochaetella, Myxarium, Protodontia, and Stypella (Heterobasidiomycetes). Mycotaxon 69: 209-248.

Roberts P, Spooner BM (1998) Heterobasidiomycetes from Brunei Darussalam. Kew Bulletin 53: 631-650.

Ronquist F, Huelsenbeck JP (2003) MRBAYE S 3: Bayesian phylogenetic inference under mixed models. Bioinformatics 19: 1572-1574. http://dx.doi.org/10.1093/bioinformatics/btg180

Sotome K, Maekawa N, Nakagiri A, Lee SS, Hattori T (2014) Taxonomic study of Asian species of poroid Auriculariales. Mycol Progress 13: 987-997.

Spirin W, Zmitrovich I (2007) Frantisekia - a new polypore genus (Polyporales, Basidiomycota). Czech Mycol 59: 141152.

Tamura K, Stecher G, Peterson D, Filipski A, Kumar S (2013) MEGA6: Molecular Evolutionary Genetics Analysis Version 6.0. Molecular Biology and Evolution 30: 2725-2729. http://dx.doi.org/10.1093/molbev/mst197

Thiers B (2017) Index Herbariorum: a global directory of public herbaria and associated stuff [continuosly updated]. New York Botanical Garden's Virtual Herbarium. http://sweetgum.nybg.org/ih (accessed on 20.12.2017)

Weiss M, Oberwinkler F (2001) Phylogenetic relationships in Auriculariales and related groups - hypotheses derived from nyclear ribosomal DNA sequences. Mycol Research 105: 403-415.

Wells K (1958) Studies in some Tremellaceae. II. The genus Ductifera. Mycologia 50: 407-416.

Wells K, Raitviir A (1975) The species of Bourdotia and Basidiodendron (Tremellaceae) of the USSR. Mycologia 67: 904-922.

Zhou LW, Dai YC (2013) Phylogeny and taxonomy of poroid and lamellate genera in the Auriculariales (Basidiomycota). Mycologia 105: 1219-1230.

Table 1. Data for ITS and nrLSU sequences used in the phylogenetic analyses

Legends

Fig. 1. Combined phylogenetic nrITS+nrLSU topology from Maximum Likelihood analysis showing main lineages within Auriculariales. All sequences generated for this study are indicated in bold faces. Collection numbers are given for newly sequenced specimens and accession numbers for additional sequences retrieved from GenBank. Support values (ML/BA) are given above the branches. Scale bar shows expected changes per site.

Fig. 2. Microscopic structures of Protohydnum cartilagineum (epitype, SP467240): hymenium and basidiospores. Scale bar $=10 \mu \mathrm{m}$.

Fig. 3. Microscopic structures of Hyalodon antui (holotype): subicular hyphae with basidia and basidiospores. Scale bar = $10 \mu \mathrm{m}$. 
Fig. 4. Microscopic structures of Hyalodon piceicola (Spirin 11063): hymenium, tramal hyphae and basidiospores. Scale bar $=10 \mu \mathrm{m}$.

Fig. 5. Basidiocarps: a - Elmerina cladophora (Miettinen 14314), b-Elmerina sclerodontia (Miettinen 16431), c Hyalodon piceicola (Spirin 2689), d - Protohydnum cartilagineum (SP467240). Scale bar $=10 \mathrm{~mm}$ 